\section{Rooting of Rhododendron 'Anna Rose Whitney' Cuttings as Related to Stem Carbohydrate Concentration}

\author{
Christopher J. French ${ }^{1}$ \\ Saanichton Research and Plant Quarantine Station, Agriculture Canada, \\ 8801 East Saanich Road, Sidney, B.C. V8L 1H3, Canada
}

Additional index words. stock plant irradiance, carbon dioxide

\begin{abstract}
Rooting of Rhododendron 'Anna Rose Whitney' ( $R$. griersonianum $\times$ 'Countess of Derby') was delayed in cuttings from stock plants grown in full sun, compared to cuttings from plants grown in $80 \%$ shade. In the outer stem (extracambium tissues), concentrations of glucose, sucrose, soluble carbohydrate, and total nonstructural carbohydrates were higher in cuttings from shaded stock plants. In the inner stem (intracambium tissues), where rooting originates, fructose, starch, and nonstructural carbohydrates were lower in cuttings from the shaded stock plants. Rooting percentage was reduced by $\mathrm{CO}_{2}$ mist during propagation. At 7 days, during rooting with a $\mathrm{CO}_{2}$ enrichment to $1100 \mu \mathrm{l} \cdot \mathrm{liter}^{-1}$, fructose in the inner stem was 3-fold higher than in cuttings rooted under atmospheric $\mathrm{CO}_{2}\left(340 \mu 1 \cdot\right.$ liter-1). Under $\mathrm{CO}_{2}$ mist, total nonstructural carbohydrate concentration was higher in the inner stem throughout the rooting period. For both high stock plant irradiance and $\mathrm{CO}_{2}$ enrichment during propagation, there was an inverse relationship between fructose concentration in the inner stem and rooting. A possible mechanism for inhibition by fructose is proposed.
\end{abstract}

Carbohydrate is generally assumed to be the energy source for adventitious root production; numerous studies in a wide variety of species have attempted to increase rooting using treatments that would be expected to increase carbohydrate supply, such as $\mathrm{CO}_{2}$ enrichment and supplementary irradiance (Carpenter et al., 1973; Moe, 1977; Davis and Potter, 1983). In some species, rooting was increased by such treatments, but inhibition has also been noted (Lovell et al., 1972 Hansen and Eriksen, 1974; French and Lin, 1984). Attempts to relate rooting to changes in soluble and insoluble carbohydrate reserves have had, varying results, depending on the species studied and environmental conditions used (Lovell et al., 1974; Hansen et al., 1978; Jung et al., 1981; Haissig, 1984; Davis and Potter, 1987).

Rhododendrons are generally propagated from stem cuttings (Leach, 1961). Carbon dioxide mist inhibited rooting of Rhododendron 'Anna Rose Whitney' when applied either before or during propagation in the fall (French, 1989). High stock plant irradiance has been shown to inhibit subsequent rooting in $R$. 'Roseum elegans' (Johnson and Roberts, 1971). These results suggested that rooting in some cultivars might be related to carbohydrate levels before or during propagation; however, there was little relationship between stem carbohydrate levels and root-

\footnotetext{
Received for publication 26 Dec. 1988. Technical assistance from J. Alsbury and graphics by S.W. MacDiarmid are gratefully acknowledged. The cost of publishing this paper was defrayed in part by the payment of page charges. Under postal regulations, this paper therefore must be hereby marked advertisement solely to indicate this fact.

'Present address: Agriculture Canada, Research Station, 6660 N.W. Marine Dr., Vancouver, B. C., Canada, V6T $1 \mathrm{X} 2$
}

ing in $R$. 'Roseum elegans' (Davis and Potter, 1987).

The present study was conducted to modulate stem carbohydrate content in $R$. 'Anna Rose Whitney' using various stock plant irradiances and $\mathrm{CO}_{2}$ levels during rooting in an attempt to relate stem carbohydrate concentration to rooting.

Shading. Stock plants for propagation were produced as follows: Rooted liners were transplanted into 6-liter containers filled with 3 bark : 1 sawdust : 1 peat : 1 sand (by volume) and the following amendments (per cubic meter): dolomitic lime, $2.1 \mathrm{~kg} ; 20 \%$ superphosphate, $1.8 \mathrm{~kg}$; and fritted trace elements, $0.075 \mathrm{~kg}$. Nutricote $16 \mathrm{~N}-4.3 \mathrm{P}-8.3 \mathrm{~K}$, 3 Type 180:1 Type 40 (w/w) (Chisso Asahi Fertilizer Co., Tokyo), was incorporated at transplanting at a rate of $4.7 \mathrm{~kg} \cdot \mathrm{m}^{-3}$. In early May of each year, plants were top-dressed with $20 \mathrm{~g}$ of Nutricote. At the end of May, 603 -year-old plants were assigned at random to two treatments: a) full sun or b) unheated woodframe greenhouse with total light transmission of $20 \%$ (French, 1985). In each treatment, plants were watered daily by overhead irrigation. In December, cuttings were taken at random from each treatment and rooted under intermittent mist in the above greenhouse, as described by French (1985). Cuttings were given a single wound and treated with $0.8 \%$ indolebutyric acid in talc before propagation. There were six replications of five cuttings for each stock plant treatment. Blocking was arranged to accommodate variations in natural irradiance within the propagation house. After 11 weeks, rooting was assessed by measuring rooting percentage and rootball dimensions (diameter and depth). Means were separated by Student's $t$ test at $P=0.05$. Carbohydrate content of the inner and outer stem base was measured on 10 cuttings from each treatment at the start of rooting. Means were separated by analysis of variance and Duncan's multiple range test at $P=0.05$. Transformation of percentage data was unnecessary, as judged by Bartlett's test for homogeneity of variance.

$\mathrm{CO}_{2}$ misting. Containerized stock plants in mix and amendments as above were grown in an unheated fiberglass greenhouse with $50 \%$ light transmission from May to December. Cuttings were taken and rooted in a glass greenhouse with 35\% light transmission, as described by French (1985). Cuttings were treated with either $\mathrm{CO}_{2}$ mist, giving an air enrichment to $1100 \mu \mathrm{l} \cdot$ liter $^{-1}$ or tap water mist from sunrise to sunset at a frequency of $10 \mathrm{sec}$ per $10 \mathrm{~min}$ (French and Lin, 1984). At intervals from the start of propagation, five cuttings were removed from each treatment and analyzed for carbohydrates. Blocking was arranged to accommodate variation in natural irradiance within the propagation house. Mean separation was by least significant difference at $P=0.05$. Rooting was assessed on 25 cuttings per treatment after 5 weeks of propagation. Mean separation was by Student's $t$ test.

Carbohydrate analysis. Methods were based on those previously described (Haissig and Dickson, 1979; Potter and Breen, 1980). The stem base was excised and divided into a lower $2.5-\mathrm{cm}$ and an upper $1-\mathrm{cm}$ section. Each stem section was further subdivided into inner and outer stem tissues longitudinally along the cambium. Outer and inner stem sections refer to tissues external and internal to the cambium, respectively. The $1-\mathrm{cm}$ segments were taken to determine fresh : dry weight ratio by drying to constant weight at $70 \mathrm{C}$, and the $2.5-\mathrm{cm}$ segments were used for carbohydrate analysis.

Immediately following excision and division, the $2.5-\mathrm{cm}$ segments were dropped into $5 \mathrm{ml}$ of boiling $80 \%$ ethanol and heated for $10 \mathrm{~min}$. The segments were homogenized with a Polytron (Brinkmann, Westbury, N. Y.) and again boiled for $5 \mathrm{~min}$. Homogenates were centrifuged at $10,000 \times \mathrm{g}$ for $10 \mathrm{~min}$ and the supernatant removed. The pellet was washed with $5 \mathrm{ml}$ of $80 \%$ ethanol and boiled for $5 \mathrm{~min}$. The procedure was repeated four times. The combined supernatants were dried in a rotary evaporator at $40 \mathrm{C}$ and dissolved in $3 \mathrm{ml}$ of $0.3 \mathrm{M}$ triethanolamine $/ \mathrm{HCl}$ buffer (pH 7.0) containing $3 \mathrm{~mm} \mathrm{MgCl}$. The ethanol insoluble fraction was dried overnight at $70 \mathrm{C}$ and resuspended in $2 \mathrm{ml}$ of $0.1 \mathrm{M} \mathrm{Na}$ acetate buffer, $\mathrm{pH}$ 4.8. Samples were stored at - 20C before analysis.

Soluble carbohydrate analysis. Glucose, fructose, and sucrose were determined enzymatically by following changes in optical density at $340 \mathrm{~nm}$ (Bergmeyer, 1963); 0.03 to $0.05 \mathrm{ml}$ of sample was added to a solution containing $1 \mathrm{~mm}$ nicotinamide adenine dinucleotide phosphate (NADP) (Sigma), $5 \mathrm{~mm}$ adenosine 5'-triphosphate (ATP) (Sigma), and $3 \mathrm{~mm} \mathrm{MgCl}$ in $0.3 \mathrm{M}$ triethanolamine $/ \mathrm{HCl}$ ( $\mathrm{pH} 7.0$ ), giving a final volume of $1.0 \mathrm{ml}$. Glucose was determined by adding $3 \mathrm{IU}$ glucose-6-phosphate dehydrogenase (EC 
1.1.1.49) (Sigma Type VII) followed by 2 IU hexokinase (EC 2.7.1.1) (Sigma Type C130). After completion of the reaction (10 $\mathrm{min}$ ), $3 \mathrm{IU}$ of phosphoglucoseisomerase (EC 5.3.1.9) (Sigma Type III) was added to measure fructose + fructose-6-phosphate. Fol-

lowing completion (15 min), $0.1 \mathrm{ml}$ (400 IU) of invertase (EC 3.2.1.26) (Sigma Grade VII) in $0.1 \mathrm{M} \mathrm{Na}$ acetate buffer ( $\mathrm{pH} 4.8$ ) was added to determine sucrose (30-min reaction). Separate samples $(0.1 \mathrm{ml})$ were checked for glucose-6-phosphate and fructose-6-

Table 1. Carbohydrate concentration in the stem base of Rhododendron 'Anna Rose Whitney' as related to stock plant irradiance. Data taken at the beginning of the rooting period.

\begin{tabular}{|c|c|c|c|c|}
\hline \multirow[b]{3}{*}{ Carbohydrate } & \multicolumn{4}{|c|}{ Irradiance treatment } \\
\hline & \multicolumn{2}{|c|}{0 Shade $^{2}$} & \multicolumn{2}{|c|}{$80 \%$ Shade $^{y}$} \\
\hline & Outer stem ${ }^{x}$ & Inner stem ${ }^{w}$ & Outer stem. & Inner stem \\
\hline & $\because$ & \multicolumn{2}{|c|}{$\mathrm{mmol} / \mathrm{g} d r y \mathrm{w} t^{\mathrm{v}}$} & \\
\hline Glucose & $0.20 \mathrm{~b}$ & $0.09 \mathrm{c}$ & $0.26 \mathrm{a}$ & $0.08 \mathrm{c}$ \\
\hline Fructose & $0.07 \mathrm{~b}$ & $0.09 \mathrm{a}$ & $0.07 \mathrm{~b}$ & $0.07 \mathrm{~b}$ \\
\hline Sucrose & $0.05 \mathrm{~b}$ & $0.05 \mathrm{~b}$ & $0.06 \mathrm{a}$ & $0.05 \mathrm{~b}$ \\
\hline $\begin{array}{l}\text { Measured soluble } \\
\text { carbohydrate }^{u}\end{array}$ & $0.32 \mathrm{~b}$ & $0.23 \mathrm{c}$ & $0.39 \mathrm{a}$ & $0.20 \mathrm{c}$ \\
\hline Starch & $0.002 \mathrm{c}$ & $0.020 \mathrm{a}$ & $0.002 \mathrm{c}$ & $0.012 b$ \\
\hline $\begin{array}{l}\text { Total nonstructural } \\
\text { carbohydrate }\end{array}$ & $0.32 \mathrm{~b}$ & $0.25 \mathrm{c}$ & $0.39 \mathrm{a}$ & $0.21 \mathrm{~d}$ \\
\hline
\end{tabular}

${ }^{z}$ Stock plants grown in full sun before propagation.

y Stock plants grown in $80 \%$ shade before propagation.

xTissues external to cambium.

"Tissues internal to cambium.

'Mean separation in rows by Duncan's multiple range test, $P=0.05$; each mean was calculated from 10 cuttings.

"Glucose + fructose + sucrose.

Total soluble carbohydrate + starch.
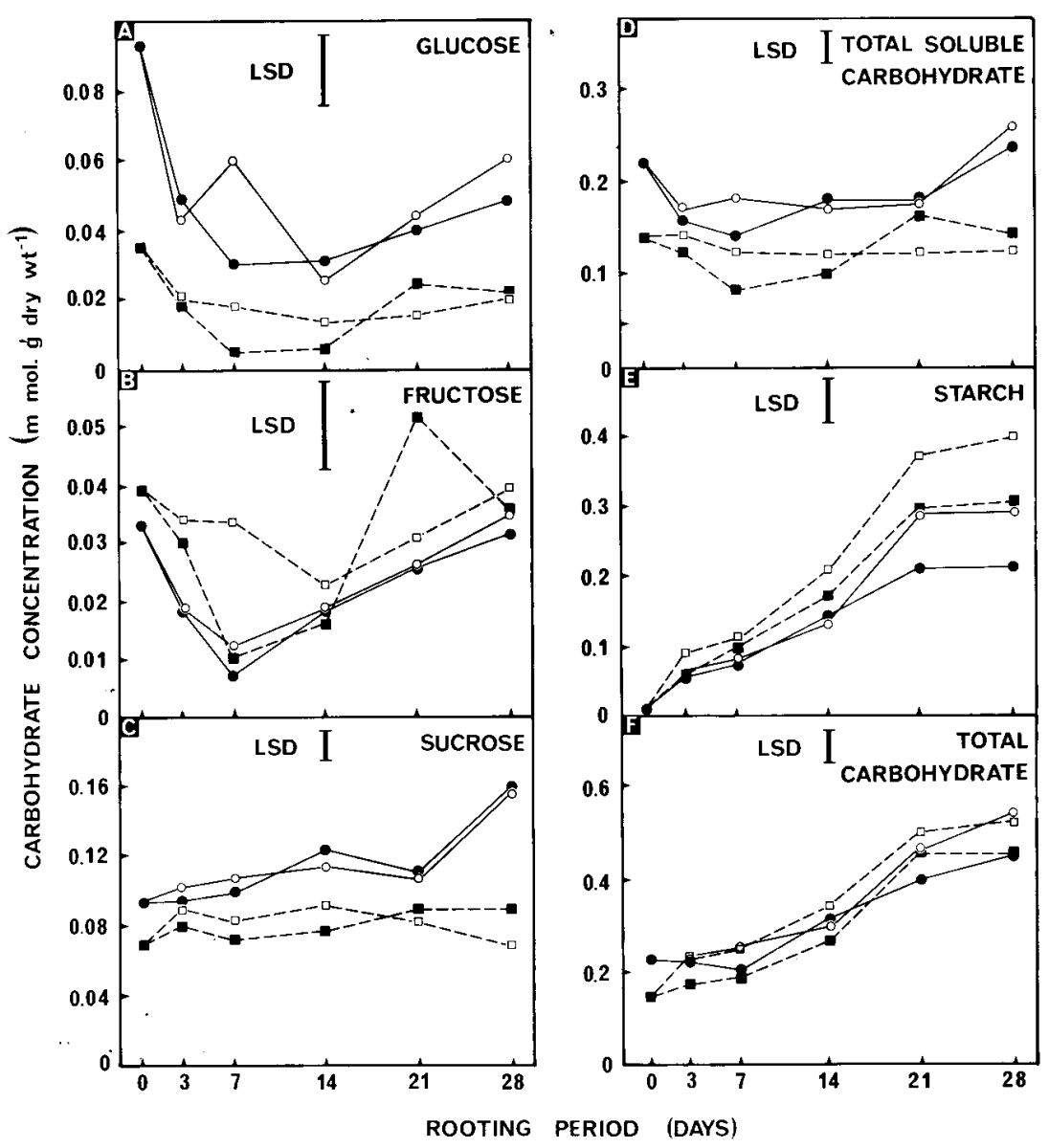

Fig. 1. Carbohydrate concentration in stem base of Rhododendron 'Anna Rose Whitney' during rooting. $\square--\square$ Inner stem $+\mathrm{CO}_{2}$ mist, $\mathbf{\square}--\mathbf{\square}$ inner stem + tap water mist. $\mathrm{O}-\mathrm{O}$ Outer stem $+\mathrm{CO}_{2}$ mist, outer stem + tap water mist. Inner and outer stem refers to tissues internal and external to the cambium, respectively. Total soluble carbohydrate $=$ glucose + fructose + sucrose; total carbohydrate = total soluble carbohydrates + starch (total nonstructural carbohydrate). Error bars show the LSD at 5\% probability. Each point is the mean of five cuttings. phosphate by adding glucose-6-phosphate dehydrogenase followed by phosphoglucoseisomerase to the standard reaction mixture. Experiments with standards and the addition of known quantities of glucose, fructose, and sucrose to plant extracts showed estimated tissue carbohydrate to be accurate within $10 \%$.

Starch determination. Starch was determined as glucose equivalents, based on previous methods (Haissig and Dickson, 1979; Potter and Breen, 1980). Starch suspension (0.5 $\mathrm{ml}$ ) was boiled for $15 \mathrm{~min}$ to gelatinize starch. Following cooling, $1 \mathrm{ml}$ of a $2-\mathrm{mg} \cdot \mathrm{ml}^{-1}$ solution of amyloglucosidase (12 IU; EC 3.2.1.3) (Boehringer-Mannheim) in $0.1 \mathrm{M} \mathrm{Na}$ acetate buffer ( $\mathrm{pH} 4.8$ ) was added. The mixture was incubated at 45 to $50 \mathrm{C}$ for $24 \mathrm{hr}$. After centrifugation at $2000 \times \mathrm{g}$ for $10 \mathrm{~min}$, the supernatant was assayed for glurcose as described above. Controls containing plant material without amyloglucosidase were incubated concurrently, assayed for glucose, and used to correct estimates of starch. Digestion of starch was checked for completion as follows: at the end of $24 \mathrm{hr}$, the precipitate was extensively homogenized and boiled for $15 \mathrm{~min}$. Fresh amyloglucosidase (12 IU) was added, and the mixture incubated again for $24 \mathrm{hr}$. No glucose was released during the second incubation.

Shading. In the outer stem, glucose, sucrose, soluble carbohydrate, and total nonstructural carbohydrate concentrations were higher in cuttings from the shaded plants than in those grown in full sun (Table 1). In contrast, in the inner stem, fructose, starch, and total nonstructural carbohydrate were lower in cuttings from the shaded stock plants. After 11 weeks, rooting of cuttings from stock plants grown in full sun was slower than those from shaded stock plants, as judged by significantly smaller rootball dimensions (Table 2). Rooting percentage was not affected.

$\mathrm{CO}$, misting. At 7 days, cuttings rooted under $\mathrm{CO}_{2}$ mist showed a higher glucose and total soluble carbohydrate concentration in the outer stem tissues when compared to cuttings rooted with tap water (Fig. 1 A and D). Starch was also higher in cuttings rooted with $\mathrm{CO}_{2}$ enrichment between 21 and 28 days of rooting (Fig. 1E). In the inner stem, $\mathrm{CO}_{2}$ mist promoted higher concentrations of total soluble carbohydrate at 7 days of rooting (Fig. 1D). Nonstructural carbohydrate was significantly higher than the control throughout the initial 14-day rooting period. Fructose showed the most difference between treatments, being 3 -fold higher in the inner stem after 7 days of propagation (Fig. 1B). After 21 days of rooting, fructose was $50 \%$ lower in the $\mathrm{CO}_{2}$ treatment, compared to the control. The pattern of starch accumulation was similar to the outer stem tissues (Fig. 1E). Rooting after 35 days was significantly less in the $\mathrm{CO}_{2}$ treated cuttings, as judged by rooting percentage (Table 2).

The stem of 'Anna Rose Whitney' contains a prominent cambium region, allowing the stem to be easily divided into inner and outer regions. The outer stem consisted of cuticle, a spongy cortex, schlerenchyma, and phloem. The inner stem contained primary 
Table 2. Effect of stock plant irradiance or $\mathrm{CO}_{2}$ enrichment on rooting of Rhododendron 'Anna Rose Whitney'.

\begin{tabular}{|c|c|c|}
\hline \multirow[b]{2}{*}{ Variable } & \multicolumn{2}{|c|}{ Irradiance treatments } \\
\hline & 0 Shade $^{z}$ & $80 \%$ Shade $^{y}$ \\
\hline $\begin{array}{l}\text { Percentage rooted } \\
\text { Rootball diam }(\mathrm{cm})^{\mathrm{w}} \\
\text { Rootball depth }(\mathrm{cm})\end{array}$ & $\begin{array}{l}90 \\
3.1^{*} \\
1.9^{*}\end{array}$ & $\begin{array}{r}97 \\
4.6 \\
4.2\end{array}$ \\
\hline \multirow{2}{*}{ Rootball depth (cm) } & \multicolumn{2}{|c|}{$\mathrm{CO}_{2}$ treatments } \\
\hline & $\mathrm{CO}_{2}$ mist $^{\mathrm{v}}$ & Tap water mist \\
\hline $\begin{array}{l}\text { Percentage rooted' } \\
\text { Rootball diam }(\mathrm{cm}) \\
\text { Rootball depth }(\mathrm{cm})\end{array}$ & $\begin{array}{l}60^{*} \\
1.6 \\
1.0\end{array}$ & $\begin{array}{l}92 \\
1.9 \\
1.1\end{array}$ \\
\hline
\end{tabular}

${ }^{2}$ Stock plants grown in full sun before propagation.

'Stock plants grown in $80 \%$ shade before propagation.

*Data taken after 11 weeks (10 Dec.-22 Feb.).

wUnrooted cuttings were not considered in calculating rootball dimensions.

${ }^{ } \mathrm{CO}_{2}$ mist was supplied from sunrise to sunset, average enrichment to $1100 \mu \mathrm{l} \cdot$ liter $^{-1}$.

"Tap water mist from sunrise to sunset; $\mathrm{CO}_{2}$ concentration $\approx 340 \mu \mathrm{I} \cdot \mathrm{liter}^{-1}$.

'Data taken after 5 weeks ( 25 Nov. -30 Dec.).

*Significantly different from paired mean at $P=$ 0.05 (Student's $t$ test).

xylem, xylem parenchyma, and a central parenchyma pith. Root initials originate in the xylem parenchyma in Rhododendron (Leach, 1961). Because of this pattern, changes in carbohydrate concentration in the inner stem may be more closely related to rooting than those of the outer stem.

Using two independent methods to modulate stem carbohydrate concentrations, rooting speed of $R$. 'Anna Rose Whitney' cuttings was found to be inversely related only to total nonstructural carbohydrate and fructose in the inner stem in the early stages of rooting. There was no correlation between total stem carbohydrate (i.e., inner and outer stems combined) and rooting. This finding is in agreement with the results of Davis and Potter (1987), who were unable to find a correlation between stem carbohydrate concentrations and rooting in $R$. 'Roseum elegans'. The higher carbohydrate concentration in the outer stem of the shaded plants was an unexpected finding. Evidently, there are differences in partitioning of carbohydrate in the inner and outer stems between sun- and shade-grown plants.

A biochemical basis for inhibition of rooting by increased carbohydrate concentrations is unknown. Total nonstructural carbohydrate concentrations in the stem base increased throughout the rooting period (Fig. $1 \mathrm{~F})$, showing that the supply of sucrose from the leaves was continuously in excess of the metabolic requirements of the stem. This result implies that factors other than total carbohydrate reserves must be limiting rooting.

Although the results do not necessarily point to a cause-and-effect relationship between rooting and carbohydrate concentration, it was noteworthy that changes in fructose were specific to the region of the stem supporting root initiation. Possibly, higher concentrations of fructose may inhibit sucrose synthase, catalyzing the reversible reaction:

$$
\text { sucrose + UDP } \leftrightharpoons \underset{\text { fructose. }}{\text { UDP-glucose }+}
$$

In the direction of uridine 5'-diphosphoglucose (UDP-glucose) formation, fructose inhibits the reaction (Doehlert, 1987) at a concentration found in the inner stems of $R$.

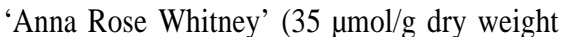
or $100 \mu \mathrm{mol} / \mathrm{g}$ fresh weight). It is therefore possible that inhibition of sucrose synthase by excess fructose could reduce the availability of sucrose for rooting.

\section{Literature Cited}

Bergmeyer, H.U. 1963. Methods of enzymatic analysis. Academic Press, New York.

Carpenter, W.J., G.R. Beck, and G.A. Anderson. 1973. High intensity supplementary lighting during rooting of herbaceous cuttings. HortScience 8:338-340.

Davis, T.D. and J.R. Potter. 1983. High CQapplied to cuttings: Effects on rooting and subsequent growth of ornamental species. HortScience 18:194-196.

Davis, T.D. and J.R. Potter. 1987. Physiological response of Rhododendron cuttings to different light levels during rooting. J. Amer. Soc. Hort. Sci. 112:256-259.

Doehlert, D.C. 1987. Substrate inhibition of maize endosperm sucrose synthase by fructose and its interaction with glucose inhibition. Plant Science 52:153-157.

French, C.J. 1985. Effects of supplementary light- ing on rooting of rhododendrons. HortScience 20:706-708

French, C.J. 1989. Propagation and subsequent growth of Rhododendron cuttings; varied response to $\mathrm{CO}_{2}$ enrichment and supplementary lighting. J. Amer. Soc. Hort. Sci. 114:251-259.

French, C.J. and W.C. Lin. 1984. Seasonal variations in the effects of $\mathrm{CO}_{2}$ mist and supplementary lighting from high pressure sodium lamps on rooting of English holly cuttings. HortScience 19:519-521.

Haissig, B.E. 1984. Carbohydrate accumulation and partitioning in Pinus banksiana seedlings and seedling cuttings. Physiol. Plant. 61:1319.

Haissig, B.E. and R.E. Dickson. 1979. Starch measurement in plant tissue using enzymatic hydrolysis. Physiol. Plant. 47:151-157.

Hansen, J. and E.N. Eriksen. 1974. Root formation of pea cuttings in relation to the irradiance of the stock plants. Physiol. Plant. 32:170-173.

Hansen, J., L.-H. Stromquist, and A. Ericsson. 1978. Influence of the irradiance on carbohydrate content and rooting of cuttings of pine seedlings (Pinus sylvestrisL.). Plant Physiol. 61:975-979.

Johnson, C.R. and A.N. Roberts. 1971. The effect of shading Rhododendron stock plants on flowering and rooting. J. Amer. Soc. Hort. Sci. 96:166-168

Jung, J. H., S.K. Chang, and D.Y. Yeam. 1981. The seasonal changes of major nutrients and rooting potentials of Rhododendron species. J. Kor. Soc. Hort. Sci . 22:92-106.

Leach, D.G. 1961. Rhododendrons of the world. C. Scribner's Sons, New York.

Lovell, P.H., A. Illsley, and K.G. Moore. 1972. The effects of light intensity and sucrose on root formation, photosynthetic ability and senescence of Sinapis alba L. and Raphanus sativus L. Ann. Bot. 36:123-134.

Lovell, P.H., A. Illsley, and K.G. Moore. 1974. Endogenous sugar levels and their effects on root formation and petiole yellowing of detached mustard cotyledons. Physiol. Plant. 31:231-236.

Moe, R. 1977. Effect of light, temperature and $\mathrm{CO}_{2}$ on the growth of Campanula isophylla stock plants and on the subsequent growth and development of their cuttings. Scientia Hort. 6:129141

Nanda, K.K., M.K. Jain, and S. Malhotra. 1971. Effect of glucose and auxins in rooting etiolated stem segments of Populus nigra. Physiol. Plant. 24:387-391.

Potter, J.R. and P.J. Breen. 1980. Maintenance of high photosynthetic rates during the accumulation of high leaf starch levels in sunflower and soybean. Plant Physiol. 66:528-531. 